Penelitian

\title{
Evaluasi Status Reproduksi Domba Garut Jantan Tipe Tangkas
}

\author{
(Evaluation of Reproduction Status of Bantam Type of Garut Ram) \\ Surya Kusuma Wijaya', Ligaya ITA Tumbelaka ${ }^{2 *}$, Iman Supriatna ${ }^{2}$, Daisy Tambajong' \\ 'Program Diploma IPB, Jalan Kumbang No 14, Bogor 16151 \\ ${ }^{2}$ Divisi Reproduksi dan Kebidanan, Departemen Klinik, Reproduksi, dan Patologi, Fakultas Kedokteran Hewan, \\ Institut Pertanian Bogor, Jalan Agatis, Kampus IPB Dramaga, Bogor, 16680 \\ *Penulis untuk korespondensi: ligaya290212@gmail.com \\ Diterima 16 Mei 2018, Disetujui 21 September 2018
}

\begin{abstract}
ABSTRAK
Domba garut merupakan salah satu aset plasma nutfah Jawa Barat yang memiliki potensi untuk dikembangkan sebagai sumber daging. Domba garut memiliki keunikan tersendiri, terutama untuk jenis garut jantan tipe tangkas, sebagai daya tarik wisata daerah. Tujuan penelitian ini adalah untuk mengevaluasi hubungan antara ukuran fisik domba garut jantan tipe tangkas, yaitu bobot badan, lingkar skrotum, dan produksi semen dengan status reproduksi domba jantan. Penelitian ini dilakukan dengan mengukur hewan coba secara fisik pada kelompok umur 3 bulan, 6-12 bulan, 13-18 bulan, 19-24 bulan, dan 36-48 bulan. Evaluasi semen dilakukan pada semua kelompok umur. Pemilihan domba jantan garut tipe tangkas didasarkan pada sifat kualitatif dan kuantitatif. Sifat kualitatif (bentuk tanduk) yang dipilih oleh petani ialah gayor (44,44\%), ngabendo (33,33\%), leang (16,67\%), dan ngagolong tali $(5,56 \%)$. Sifat kuantitatif meliputi bobot badan, lingkar skrotum, dan panjang skrotum pada domba jantan, yang meningkat sampai kelompok usia 18-24 bulan. Evaluasi semen menunjukkan nilai tertinggi ditemukan pada kelompok usia 18-24 bulan. Bentuk tanduk tipe tangkas tidak memiliki korelasi dengan bobot badan, lingkar skrotum, dan panjang skrotum garut jantan secara statistik.

Kata kunci: tipe tangkas, domba garut jantan, status reproduksi
\end{abstract}

\begin{abstract}
Garut sheep is one of the West Java germ-plasma assets, which has a good potential to be developed as a source of meat. Garut sheep has a unique advantage, especially for bantam type of garut ram, as a regional tourism attraction. The aim of this study was to evaluate the correlation among physical measures of bantam type of garut ram i.e., body weight, scrotum circumference, and semen production with the reproduction status of rams. This study was conducted to measure some physical measures of experimental rams at the ages of 3-months, 6-12 months, 13-18 months, 19-24 months, and 36-48 months. Semen evaluation was conducted in all age groups. Selection of bantam type of garut ram was based on qualitative and quantitative traits. Qualitative trait (horn form) was selected by farmer i.e., gayor (44,44\%), ngabendo (33,33\%), leang (16,67\%), and ngagolong tali (5,56\%). Quantitative traits included body weight, scrotum circumference, and the length of the scrotum in the ram that increased until the age of 18-24 months. Semen evaluation showed that the highest value was found in the ram at the age group of 18-24 months. The bantam type of horn form had no statistical correlation with body weight, scrotum circumference, and scrotum length of garut ram.
\end{abstract}

Keywords: bantam type, garut ram, reproduction status 


\section{PENDAHULUAN}

Domba merupakan hewan ternak penghasil daging, susu, kulit, dan produk lainnya untuk kepentingan hidup manusia. Domba garut sebagai aset plasma nutfah Jawa Barat, memiliki potensi yang baik untuk dikembangkan sebagai sumber daging. Domba garut cukup tanggap terhadap manajemen pemeliharaan yang baik dibandingkan domba lokal dan bangsa domba lain yang ada di Indonesia. Domba garut juga memiliki keunggulan unik yang dapat dijadikan daya tarik pariwisata daerah, khususnya untuk domba garut tipe tangkas (Heriyadi, 2005).

Domba garut jantan memiliki naluri untuk bertarung sehingga pemeliharaannya menghasilkan seleksi domba garut tipe tangkas. Domba tangkas memiliki karakteristik yang terpilih seperti bentuk tanduk, bentuk muka, telinga, konformasi tubuh, bentuk dada, ekor, testis, dan pola warna rambut. Unsur seleksi tersebut tidak terlalu tampak pada domba garut tipe pedaging. Sifat-sifat kualitatif domba garut jantan tipe tangkas menurut Heriyadi (2005) sebagai berikut: 1) Karakteristik warna bulu dominan pada domba garut jantan adalah kombinasi warna hitam-putih, yaitu sebesar $86 \%$. 2) Motif rambut dominan pada domba garut jantan adalah hitam atau hideung polos (19,83\%) dan belang sapi $(14,88 \%) .3)$ Bentuk tanduk dominan pada domba garut jantan adalah Gayor (54,95\%), Ngabendo (17,36\%) dan Leang $(16,53 \%)$.

Beberapa keunggulan domba garut dibandingkan dengan domba lainya menurut Gunawan dan Noor (2005) di antaranya memiliki keunggulan komparatif, terutama dalam hal performa dan kekuatannya serta memiliki bobot badan yang dapat bersaing dengan domba impor dalam hal kualitas dan produktivitas. Istiqomah et al. (2006) melaporkan domba garut mempunyai bobot lahir dan bobot sapih yang tinggi, seleksi berdasarkan bobot sapih dapat meningkatkan bobot dewasa.

Status reproduksi hewan jantan dapat ditentukan dari pubertas, sexual maturity, dan dewasa tubuh. Pubertas atau dewasa kelamin adalah umur atau waktu pada saat alat kelamin baik jantan maupun betina mulai berfungsi dan perkembangbiakan dapat berlangsung. Menurut Lindsay et al. (1982), dewasa kelamin tidak sama dengan sexual maturity (masak kelamin). Masak kelamin adalah kemampuan maksimal testes seekor hewan jantan untuk memproduksi spermatozoa pada masa reproduktifnya yang dipengaruhi oleh faktor lingkungan dan dapat dihubungkan dengan kondisi bobot badan. Dewasa tubuh adalah kondisi organ reproduksi sudah mencapai perkembangan maksimal baik fungsi dan ukurannya. Penelitian ini bertujuan untuk mengetahui informasi status reproduksi domba garut, serta menghubungkan antara seleksi domba garut tangkas secara kualitatif (bentuk tanduk) dan kuantitatif (bobot badan, lingkar skrotum) dengan produksi semen.

\section{BAHAN DAN METODE}

\section{Waktu dan Tempat Penelitian}

Kegiatan penelitian dilakukan pada bulan Agustus sampai Desember 2016. Pelaksanaan penelitian dilakukan di peternakan domba garut Untung Tani di Malangbong, Kabupaten Garut. Pengolahan data yang diperoleh dilaksanakan di bagian Laboratorium Reproduksi, Program Diploma, Institut Pertanian Bogor.

\section{Prosedur Penelitian}

Penelitian melalui tiga tahap, yaitu persiapan hewan coba, pemeriksaan fisik, penampungan dan evaluasi semen.

\section{Persiapan Hewan Coba}

Hewan percobaan dipilih berdasarkan umur. Umur ditentukan dengan pemeriksaan gigi dan dicocokkan dengan pencatatan oleh peternak. Domba garut tipe tangkas yang tersedia di peternakan tersebut memiliki variasi umur dari 3 bulan sebanyak lima ekor, 6-12 bulan sebanyak enam ekor, 12-18 bulan sebanyak empat ekor, 18-24 bulan sebanyak dua ekor, dan >24 bulan (umur berkisar 3-4 tahun) sebanyak enam ekor. Pengamatan profil tanduk domba terhadap sifat kualitatif dan kuantitatif tidak dibedakan berdasarkan umur.

Hewan coba diberi pakan hijaun dan pakan tambahan. Pakan hijauan berupa rumput raja dan rumput lapang yang berada di sekitar peternakan. Rumput raja diberikan pada pukul 15.30 WIB dan rumput lapang diberikan pada pukul 17.00 WIB. Pakan tambahan yang diberikan berupa ampas tahu, yang diberikan pada pukul 07.00 WIB.

2. Pemeriksaan fisik

Pemeriksaan fisik dimulai dari identifikasi pejantan yang diperiksa. Sinyalemen dicatat lengkap beserta data diri pemilik. Pejantan yang diperiksa dapat berjalan bebas, tidak memiliki kepincangan dan kekakuan yang berdampak pada kelancaran percumbuan (Pezzanite et al., 2004). Kesehatan alat gerak atau ekstermitas 
harus diperiksa, terutama kaki belakang yang menjadi alat gerak penting pada saat mating (Bagley, 1997). Kuku kaki harus diperiksa. Kuku tidak boleh panjang atau sampai malformasi, foot root dan kelainan lainnya. Domba garut diperiksa secara fisik mulai dari inspeksi, palpasi, perkusi, dan auskultasi. Domba garut juga didokumentasikan secara fisik.

Organ penis, preputium, skrotum, dan testis diperiksa dengan inspeksi dan palpasi, dengan tujuan mengidentifikasi normalitas organnya dan mendeteksi adanya perlekatan, perlukaan berat, inflamasi, dan fibrosis (Hopkins \& Spitzer, 1997). Pemeriksaan dimulai dari penis, berbentuk simetris, bergerak bebas, dan tidak ada massa asing yang menempel padanya. Penis dapat memanjang total dari preputium, titik kritis pada pejantan yang baru dewasa kelamin.

Skrotum dan testis dievaluasi dari kesimetrisan, konsistensi, dan ukuran. Skrotum diukur lingkar dan panjangnya. Cara mengukur lingkar skrotum, testis dipijat agar mengarah ke bawah skrotum. Pita ukur diletakkan pada bagian skrotum yang memiliki diameter paling luas (Pezzanite et al., 2004). Panjang Skrotum dihitung dari tonjolan caput epidimis hingga ujung skrotum. Pengukuran panjang skrotum dilakukan dengan menggunakan pita ukur. Pengukuran dilakukan sebanyak dua kali untuk memastikan pengukuran yang pertama benar.

3. Kualitas semen

Semen ditampung dengan metode vagina buatan. Semen yang didapat dimasukkan ke dalam tabung pengumpul dan diberi water jacket. Semen dievaluasi secara makroskopis dan mikroskopis. Pemeriksaan makroskopis antara lain warna, konsistensi, volume, dan $\mathrm{pH}$. Pemeriksaan mikroskopis antara lain gerakan massa, estimasi konsentrasi, gerakan individu (motilitas), viabilitas (morfologi, hidup, dan mati), dan perhitungan konsentrasi dengan kamar hitung.

\section{Analisis Data}

Semua data kualitatif dianalisis secara deskriptif dan data kuantitatif dianalisis statistik. Data kuantitatif dianalisis menggunakan SPSS v. 15 dengan oneway-ANOVA post hoc Duncan test dan Ttest. Data disajikan dalam rataan dengan standar deviasi (rataan \pm SD) dan disampaikan secara deskriptif naratif.

\section{HASIL}

\section{Seleksi Domba Garut Jantan Tipe Tangkas}

Peternak domba garut sudah melakukan seleksi mengikuti standar yang sudah ditentukan. Delapan belas ekor domba garut yang terdiri atas enam ekor anakan domba garut berumur 6-12 bulan, empat anakan domba garut berumur 12-18 bulan, dua ekor domba berumur 18-24 bulan, dan enam ekor induk pejantan berumur 36-48 bulan diperiksa secara fisik. Bentuk tanduk yang dipilih peternak adalah gayor (44,44\%), ngabendo (33,33\%), leang (16,67\%), dan ngagolong tali $(5,56 \%)$ seperti yang ditunjukkan pada Gambar 1.

Seleksi kuantitatif ditentukan pada bobot lahir, bobot badan sapih, bobot badan dewasa, panjang badan, lingkar dada, dan tinggi pundak. Penelitian ini menunjukkan bahwa peternak menyapih anak domba pada umur tiga bulan dengan bobot badan sapih rata-rata $16,00 \pm 2,48 \mathrm{~kg}$. Bobot badan sapih tersebut sudah melampaui bobot sapih menurut SNI Domba Garut, yaitu 11,5 kg.

Nilai rataan hasil analisis sifat kuantitatif merupakan salah satu nilai terpenting sebagai dasar dalam memilih Domba Garut tipe tangkas, karena nilai tersebut menggambarkan kondisi parameter yang sesungguhnya yang menyangkut sifat-sifat kuantitatif domba garut tipe tangkas disajikan pada Tabel 1. Bobot badan, lingkar dada, dan panjang badan domba garut memiliki perbedaan yang nyata pada semua kelompok umur. Tinggi pundak memiliki nilai yang berbeda nyata antara kelompok umur 3 bulan dan 6-12 bulan. Tinggi pundak ke-lompok umur 6-12 bulan, sampai 18-24 bulan tidak berbeda nyata. Domba garut yang diamati pada kelompok umur 1824 bulan memililiki bobot badan 53,84 $\pm 9,63 \mathrm{~kg}$, lebar dada $87,33 \pm 6,13 \mathrm{~cm}$, panjang badan $76,12 \pm 2,99 \mathrm{~cm}$, dan tinggi pundak $64,70 \pm 3,11 \mathrm{~cm}$. Ukuran tersebut hampir sama dengan SNI domba garut yang menyebutkan sifat kuantitatif domba garut tangkas umur 18 bulan adalah bobot badan 58,o kg, lingkar dada $89,0 \mathrm{~cm}$, panjang badan $64,0 \mathrm{~cm}$, dan tinggi pundak $74,0 \mathrm{~cm}$.

\section{Dewasa Kelamin dan Dewasa Tubuh}

Dewasa kelamin adalah waktu pada saat alat kelamin mulai berfungsi dan perkembangbiakan dapat berlangsung. Hasil penelitian di lapangan menunjukkan bahwa domba garut tangkas hasil seleksi memiliki rataan panjang dan lingkar skrotum seperti yang dapat dilihat pada Tabel 2. Kelompok 

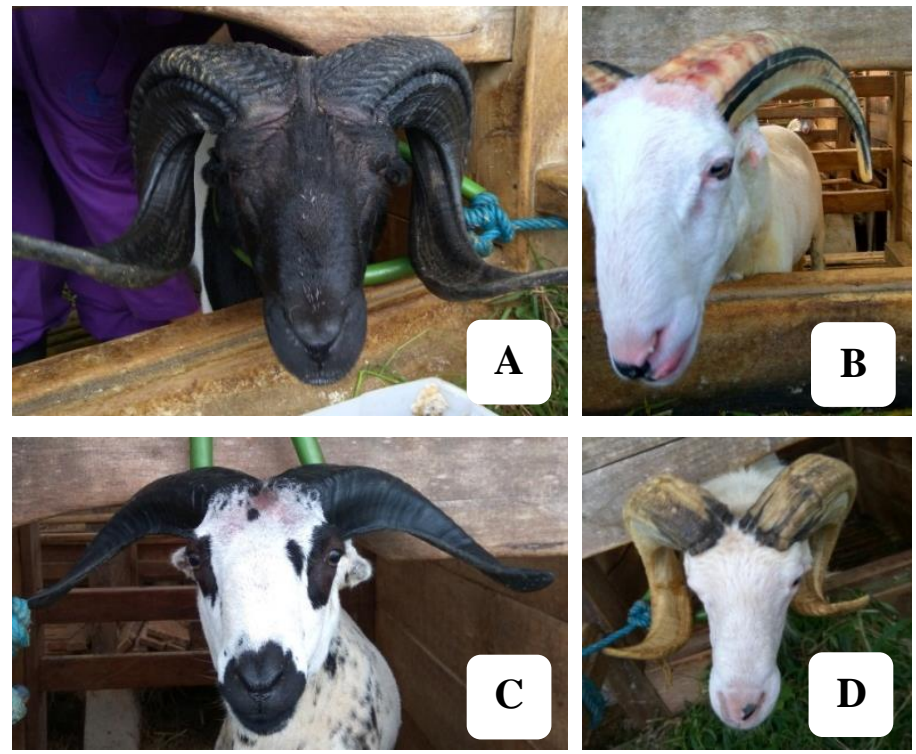

Gambar 1 Variasi bentuk tanduk domba garut tipe tangkas A. Gayor. B. Ngabendo. C. Leang. D. Ngagolong Tali

Tabel 1 Sifat-sifat kuantitatif domba garut tipe tangkas hasil pengukuran

\begin{tabular}{cccccc}
\hline $\begin{array}{c}\text { Kelompok Umur } \\
(\text { bulan })\end{array}$ & $\begin{array}{c}\sum \mathrm{n} \\
(\mathrm{ekor})\end{array}$ & $\begin{array}{c}\text { Bobot Badan } \\
(\mathrm{kg})\end{array}$ & $\begin{array}{c}\text { Lingkar Dada } \\
(\mathrm{cm})\end{array}$ & $\begin{array}{c}\text { Panjang Badan } \\
(\mathrm{cm})\end{array}$ & $\begin{array}{c}\text { Tinggi Pundak } \\
(\mathrm{cm})\end{array}$ \\
\hline 3 & 5 & $16,05 \pm 2,48^{\mathrm{a}}$ & $58,40 \pm 2,97^{\mathrm{a}}$ & $50.70 \pm 2,73^{\mathrm{a}}$ & $47,70 \pm 2,78^{\mathrm{a}}$ \\
$6-12$ & 6 & $36,61 \pm 5,36^{\mathrm{b}}$ & $77,33 \pm 4,12^{\mathrm{b}}$ & $65,98 \pm 3,32^{\mathrm{b}}$ & $60,47 \pm 2,35^{\mathrm{b}}$ \\
$12-18$ & 4 & $45,72 \pm 4,60^{\mathrm{c}}$ & $83,50 \pm 2,53^{\mathrm{c}}$ & $71,00 \pm 5,01^{\mathrm{c}}$ & $64,18 \pm 0,78^{\mathrm{c}}$ \\
$18-24$ & 2 & $53,84 \pm 9,63^{\mathrm{d}}$ & $87,33 \pm 6,13^{\mathrm{d}}$ & $76,12 \pm 2,99^{\mathrm{d}}$ & $64,70 \pm 3,11^{\mathrm{c}}$ \\
$36-48$ & 6 & $62,47 \pm 4,10^{\mathrm{e}}$ & $92,96 \pm 2,27^{\mathrm{e}}$ & $78,29 \pm 2,10^{\mathrm{e}}$ & $68,10 \pm 2,96^{\mathrm{d}}$ \\
\hline Keterangan: & angka yang diikuti huruf dengan superscript yang berbeda pada kolom yang sama menunjukkan perbedaan nyata \\
& & &
\end{tabular}

umur 6-12 bulan sudah mencapai dewasa kelamin dengan lingkar skrotum rata-rata $27,22 \pm 1,17 \mathrm{~cm}$ dan panjang 17,11 $\pm 1,29 \mathrm{~cm}$. Lingkar dan panjang skrotum meningkat ukurannya sampai umur 18-24 bulan. Lingkar dan panjang skrotum tidak meningkat setelah hewan berumur lebih dari 24 bulan. Hal tersebut menunjukkan bahwa pertumbuhan skrotum maksimal terjadi pada kelompok umur 1824 bulan. Dewasa tubuh merupakan proses akhir dalam pertumbuhan, pada penelitian ini diduga terjadi pada kelompok umur 18-24 bulan. Domba garut jantan mencapai bobot dewasa $(58 \mathrm{~kg})$ pada umur 18 bulan menurut SNI Domba Garut tahun 2009. Kelompok umur 18-24 bulan pada penelitian ini memiliki bobot badan yang hampir mencapai 58 kg. Pertambahan bobot setelah dewasa tubuh terjadi akibat penambahan deposit lemak.

\section{Karakteristik Fisik dan Kualitas Semen}

Kualitas semen domba garut diperiksa secara makroskopis dan mikroskopis. Parameter makroskopis yang diperiksa adalah volume, kekentalan, war- na, dan pH (Tabel 3). Hasil evaluasi makroskopis menunjukkan volume yang bervariasi dari $0,67 \pm 0,13$ sampai 1,03 $\pm 0,32 \mathrm{ml}$. Kelompok domba 36-48 bulan memiliki nilai volume yang rendah. Semen yang dikoleksi semua kental dan berwarna krem. Warna krem dan kental menunjukkan bahwa konsentrasi yang tinggi. Semen yang dikoleksi memiliki $\mathrm{pH}$ antara 6,76 $\pm 0,21-6,88 \pm 0,29$.

Parameter mikroskopis yang diujikan adalah gerakan masa, gerakan individu, estimasi konsentrasi, viabilitas, abnormalitas, dan konsentrasi (Tabel 4). Gerakan masa dari semen yang diamati

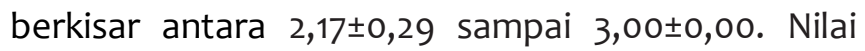
gerakan masa di atas dua menunjukkan bahwa spermatozoa bergerak bersama-sama membentuk awan tebal dan berpindah cepat. Nilai viabilitas berkisar antara $75,40 \pm 5,50$ sampai $79,27 \pm 5,03 \%$. Nilai abnormalitas dari semen yang diperiksa antara $4,00 \pm 1,41$ sampai $6,30 \pm 0,27 \%$. Persentase abnormalitas yang diperoleh masih dalam kisaran yang normal.

Gerakan individu sperma pada semen yang diamati menunjukkan peningkatan dari masing-masing 


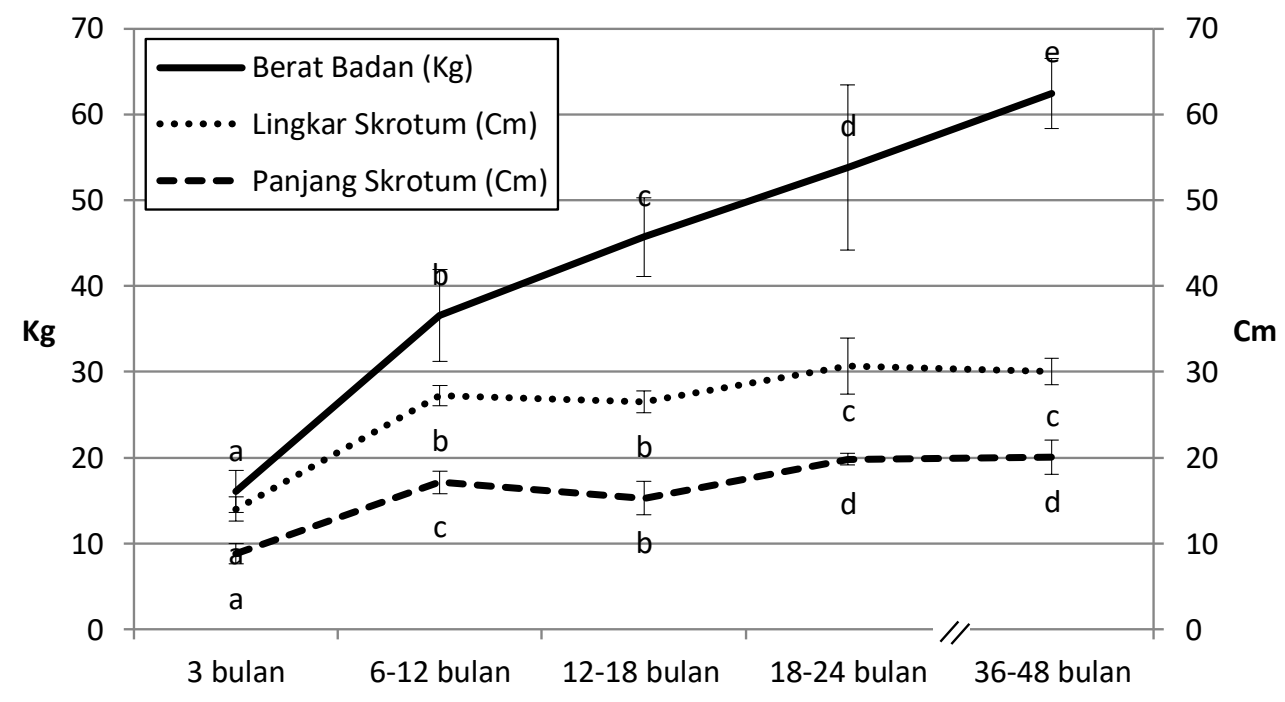

Gambar 2 Hubungan bobot badan dengan lingkar skrotum, dan panjang skrotum

Tabel 2 Rataan bobot badan, lingkar skrotum, dan panjang skrotum domba garut tipe tangkas

\begin{tabular}{ccccc}
\hline $\begin{array}{c}\text { Kelompok Umur } \\
\text { (bulan) }\end{array}$ & $\begin{array}{c}\sum \mathrm{n} \\
(\mathrm{ekor})\end{array}$ & $\begin{array}{c}\text { Bobot Badan } \\
(\mathrm{kg})\end{array}$ & $\begin{array}{c}\text { Lingkar Skrotum } \\
(\mathrm{cm})\end{array}$ & $\begin{array}{c}\text { Panjang Skrotum } \\
(\mathrm{cm})\end{array}$ \\
\hline 3 & 5 & $16,05 \pm 2,48^{\mathrm{a}}$ & $14,00 \pm 1,41^{\mathrm{a}}$ & $8,80 \pm 1,15^{\mathrm{a}}$ \\
$6-12$ & 6 & $36,61 \pm 5,36^{\mathrm{b}}$ & $27,22 \pm 1,17^{\mathrm{b}}$ & $17,11 \pm 1,29^{\mathrm{c}}$ \\
$12-18$ & 4 & $45,72 \pm 4,60^{\mathrm{c}}$ & $26,50 \pm 1,23^{\mathrm{b}}$ & $15,25 \pm 1,95^{\mathrm{b}}$ \\
$18-24$ & 2 & $53,84 \pm 9,63^{\mathrm{d}}$ & $30,67 \pm 3,30^{\mathrm{c}}$ & $19,83 \pm 0,71^{\mathrm{d}}$ \\
$36-48$ & 6 & $62,47 \pm 4,10^{\mathrm{e}}$ & $30,04 \pm 1,54^{\mathrm{c}}$ & $20,08 \pm 2,01^{\mathrm{d}}$ \\
\hline
\end{tabular}

Keterangan: angka yang diikuti huruf dengan superscript yang berbeda pada kolom yang sama menunjukkan perbedaan nyata $(\mathrm{P}<0,05)$

kelompok umur. Kelompok umur muda (6-12 bulan) memiliki nilai $62,00 \pm 7,58 \%$, kemudian meningkat sampai $75,00 \pm 7,07 \%$ pada kelompok umur $18-24$ bulan. Gerakan individu pada kelompok umur 18-24 bulan dan 36-48 bulan tidak berbeda nyata.

Konsentrasi spermatozoa pada penelitian ini berkisar antara 1,788 \pm 799 sampai $2.708 \pm 288$ juta sel/ejakulat. Konsentrasi spermatozoa total pada kelompok umur 6-12 bulan nilainya paling rendah dibandingkan kelompok umur lainnya. Hal ini disebabkan karena kelompok umur tersebut masih pubertas, sistem hormonal pada ternak belum optimal. Hormonal ini juga yang mempengaruhi proses spermatogenesis sehingga menghasilkan konsentrasi spermatozoa.

\section{Bentuk Tanduk, Sifat Kuantitatif, dan Kualitas Semen}

Bentuk tanduk merupakan sifat kualitatif yang diutamakan dalam seleksi domba garut tipe tangkas selain dari bentuk telinga, ekor, warna rambut, dan motif rambut. Pada penelitian ini, kelompok tanduk bakalan adalah domba garut tangkas lepas sapih yang akan diseleksi dan belum dapat ditentukan tipe tanduknya. Bentuk tanduk dikelompokkan menjadi tanduk gayor, tanduk ngabendo, tanduk leang, dan tanduk ngagolong tali tanpa membedakan kelompok umur (Tabel 5 ).

Uji T-test untuk membandingkan antara kelompok tanduk gayor dan ngabendo dengan hasil evaluasi semennya. Jumlah sampel yang dibandingkan sebanyak lima ekor dari masing-masing kelompok tanduk. Variasi umur pada kelompok tanduk gayor antara lain satu ekor berumur 6-12 bulan, dua ekor berumur 13-18 bulan, satu ekor berumur 19-24 tahun, dan satu ekor berumur lebih dari 48 bulan. Variasi umur pada kelompok tanduk ngabendo antara lain empat ekor berumur 6-12 bulan dan satu ekor berumur lebih dari 48 bulan. Hasil uji T-Tes dapat dilihat pada Tabel 6. 
Tabel 3 Kualitas semen domba garut tipe tangkas secara makroskopis berdasarkan kelompok umur

\begin{tabular}{cccccc}
\hline $\begin{array}{c}\text { Kelompok Umur } \\
\text { (bulan) }\end{array}$ & $\begin{array}{c}\sum \mathrm{n} \\
(\mathrm{e} \text { or) }\end{array}$ & Volume & Kekentalan & Warna & $\mathrm{pH}$ \\
\hline 3 & 5 & - & - & - & - \\
$6-12$ & 5 & $0,75 \pm 0,33^{\text {ab }}$ & Kental & Krem & $6,85 \pm 0,18^{\mathrm{a}}$ \\
$12-18$ & 3 & $0,88 \pm 0,13^{\mathrm{ab}}$ & Kental & Krem & $6,88 \pm 0,29^{\mathrm{a}}$ \\
$18-24$ & 2 & $1,03 \pm 0,32^{\mathrm{b}}$ & Kental & Krem & $6,78 \pm 0,11^{\mathrm{a}}$ \\
$36-48$ & 5 & $0,67 \pm 0,13^{\mathrm{a}}$ & Kental & Krem & $6,76 \pm 0,21^{\mathrm{a}}$ \\
\hline
\end{tabular}

Keterangan: angka yang diikuti huruf dengan superscript yang berbeda pada kolom yang sama menunjukkan perbedaan nyata $(P<0,05)$

Tabel 4 Kualitas semen domba garut tipe tangkas secara mikroskopis berdasarkan kelompok umur

\begin{tabular}{cccccccc}
\hline $\begin{array}{c}\text { Kelompok Umur } \\
\text { (bulan) }\end{array}$ & $\begin{array}{c}\sum \mathrm{n} \\
(\text { ekor) }\end{array}$ & Gerakan masa & $\begin{array}{c}\text { Gerakan Individu } \\
(\%)\end{array}$ & $\begin{array}{c}\text { Estimasi } \\
\text { konsentrasi }\end{array}$ & $\begin{array}{c}\text { Viabilitas } \\
(\%)\end{array}$ & $\begin{array}{c}\text { Abnormalitas } \\
(\%)\end{array}$ & $\begin{array}{c}\text { Konsentrasi } \\
(\text { Juta sel/ej) }\end{array}$ \\
\hline 3 & 5 & - & - & - & - & - & - \\
$6-12$ & 5 & $2,70 \pm 0,27^{\mathrm{b}}$ & $62,00 \pm 7,58^{\mathrm{ab}}$ & $\mathrm{D}$ & $75,40 \pm 5,50^{\mathrm{a}}$ & $6,30 \pm 0,27^{\mathrm{b}}$ & $1.788 \pm 799^{\mathrm{a}}$ \\
$12-18$ & 3 & $2,17 \pm 0,29^{\mathrm{a}}$ & $58,33 \pm 15,28^{\mathrm{a}}$ & $\mathrm{D}$ & $76,00 \pm 12,13^{\mathrm{a}}$ & $5,50 \pm 0,50^{\mathrm{ab}}$ & $2.685 \pm 411^{\mathrm{a}}$ \\
$18-24$ & 2 & $3,00 \pm 0,00^{\mathrm{b}}$ & $75,00 \pm 7,07^{\mathrm{b}}$ & $\mathrm{D}$ & $78,62 \pm 12,55^{\mathrm{a}}$ & $4,00 \pm 1,41^{\mathrm{a}}$ & $2.708 \pm 288^{\mathrm{a}}$ \\
$36-48$ & 5 & $2,63 \pm 0,25^{\mathrm{ab}}$ & $71,00 \pm 3,25^{\mathrm{b}}$ & $\mathrm{D}$ & $79,27 \pm 5,03^{\mathrm{a}}$ & $4,70 \pm 0,57^{\mathrm{ab}}$ & $2.186 \pm 717^{\mathrm{a}}$ \\
\hline
\end{tabular}

Keterangan: angka yang diikuti huruf dengan superscript yang berbeda pada kolom yang sama menunjukkan perbedaan nyata $(\mathrm{P}<0,05)$. $\mathrm{D}=$ Densum (estimasi konsentrasi $>10 \times 10^{9}$ juta $\mathrm{sel} / \mathrm{ml}$ ).

\section{PEMBAHASAN}

\section{Seleksi Domba Garut Jantan Tipe Tangkas}

Badan Standarisasi Nasional Indonesia (BSNI) yang dituangkan dalam SNI 7532:2009 tentang bibit domba garut menyebutkan bahwa seleksi kualitatif ditentukan pada bentuk telinga, ekor, tanduk, dan warna rambut (Gambar 1). Peternak menyeleksi domba garut jantan menjadi domba tangkas dan domba pedaging didasarkan pada karakteristik fisik yang ada pada domba tersebut. Daun telinga dipilih dengan melihat panjangnya kurang dari $4 \mathrm{~cm}$ (telinga rumpung) atau panjang $4-8 \mathrm{~cm}$ (telinga ngadaun hiris). Ekor dipilih dengan melihat bentuknya seperti segitiga pendek (ekor ngabagong) atau ekor panjang (ekor ngabuntut beurit). Tanduk dipilih dengan melihat bentuknya, yaitu tanduk berputar ke arah luar (tanduk leang), tanduk berputar ke arah setengah luar (tanduk gayor), tanduk berputar setengah lingkaran (tanduk ngabendo), atau tanduk menggulung seperti tambang (tanduk ngagolong tambang). Warna rambut yang dipilih antara lain adalah warna hitam, putih, cokelat, atau kombinasinya. Penelitian yang dilakukan oleh Heriyadi (2005) yang menyimpulkan bahwa peternak domba garut di Jawa Barat lebih menyukai bentuk tanduk gayor (54,95\%), ngabendo (17,36\%), dan leang (16,53\%). Daun telinga yang dipilih peternak semuanya bertipe rumpung (100\%). Telinga rumpung memiliki kelebihan tidak rentan terluka apabila domba garut tangkas sedang beradu.
Warna dominan putih lebih disukai oleh peternak. Warna rambut domba garut dalam penelitian ini antara lain dominan putih (77,78\%), putih totol hitam (11,11\%), putih hitam (5,56\%), dan hitam polos $(5,56 \%)$. Warna dominan putih dan warna dominan hitam merupakan warna yang lebih disukai peternak. Warna dominan putih mencapai $28,10 \%$ dan warna dominan hitam sebanyak $23,14 \%$ (Heriyadi, 2005).

Seleksi kuantitatif didasarkan pada penampilan fisik hewan. Trislawati (2006) menyebutkan bahwa anak domba yang memiliki bobot lahir besar akan lebih cepat tumbuh bila dibandingkan dengan anak domba yang lahir kecil. Hal ini sesuai dengan pernyataan Triwulaningsih (1986) bahwa bobot sapih dan bobot lahir mempunyai korelasi genetik yang bersifat positif sehingga seleksi terhadap bobot sapih akan meningkatkan bobot lahir pada generasi berikutnya. Gunawan dan Noor (2005) melakukan penelitian tentang pendugaan nilai heritabilitas bobot lahir dan bobot sapih domba garut tipe tangkas.

Nilai heritabilitas bobot sapih yang diperoleh pada kedua kelompok domba, yaitu domba garut SR dan SB berturut-turut adalah 0,95 $\pm 0,16$ dan $0,57 \pm 0,37$. Nilai heritabilitas tersebut dikategorikan tinggi, yang menunjukkan bahwa faktor genetik sangat berperan dalam menentukan keragaman fenotipik ternak sehingga dapat secara maksimal dimanfaatkan dalam peningkatan kemajuan genetik melalui program seleksi. 
Tabel 5 Profil tanduk dan sifat kuantitatif domba garut

\begin{tabular}{lccccccc}
\hline $\begin{array}{c}\text { Profil } \\
\text { Tanduk }\end{array}$ & $\begin{array}{c}\sum \mathrm{n} \\
(\mathrm{ekor})\end{array}$ & $\begin{array}{c}\text { Bobot Badan } \\
(\mathrm{kg})\end{array}$ & $\begin{array}{c}\text { Lingkar Dada } \\
(\mathrm{cm})\end{array}$ & $\begin{array}{c}\text { Panjang } \\
\text { Badan }(\mathrm{cm})\end{array}$ & $\begin{array}{c}\text { Tinggi } \\
\text { Pundak }(\mathrm{cm})\end{array}$ & $\begin{array}{c}\text { Lingkar } \\
\text { Skrotum }(\mathrm{cm})\end{array}$ & $\begin{array}{c}\text { Panjang } \\
\text { Skrotum }(\mathrm{cm})\end{array}$ \\
\hline Bakalan & 5 & $16,07 \pm 2,49^{\mathrm{a}}$ & $58,40 \pm 2,97^{\mathrm{a}}$ & $50,70 \pm 2,73^{\mathrm{a}}$ & $47,70 \pm 2,77^{\mathrm{a}}$ & $14,00 \pm 1,41^{\mathrm{a}}$ & $8,80 \pm 1,15^{\mathrm{a}}$ \\
Gayor & 8 & $54,49 \pm 10,16^{\mathrm{b}}$ & $88,42 \pm 5,44^{\mathrm{b}}$ & $74,82 \pm 5,77^{\mathrm{b}}$ & $65,79 \pm 3,02^{\mathrm{b}}$ & $29,21 \pm 2,78^{\mathrm{b}}$ & $18,43 \pm 3,55^{\mathrm{b}}$ \\
Leang & 3 & $43,17 \pm 10,12^{\mathrm{b}}$ & $81,11 \pm 6,38^{\mathrm{b}}$ & $70,22 \pm 6,09^{\mathrm{b}}$ & $62,51 \pm 1,75^{\mathrm{b}}$ & $27,44 \pm 1,26^{\mathrm{b}}$ & $16,56 \pm 0,96^{\mathrm{b}}$ \\
Ngabendo & 6 & $42,25 \pm 11,29^{\mathrm{b}}$ & $80,71 \pm 7,33^{\mathrm{b}}$ & $69,15 \pm 6,08^{\mathrm{b}}$ & $61,94 \pm 3,69^{\mathrm{b}}$ & $27,57 \pm 1,58^{\mathrm{b}}$ & $18,50 \pm 2,21^{\mathrm{b}}$ \\
Ngagolong Tali* & 1 & 66,24 & 95,50 & 78,75 & 72,00 & 29,50 & 20,00 \\
\hline
\end{tabular}

Keterangan: angka yang diikuti huruf dengan superscript yang berbeda pada kolom yang sama menunjukkan perbedaan nyata $(\mathrm{P}<0,05)$. kelompok *) tidak diikutkan dalam analisa karena $\mathrm{n}=1$

Tabel 6 Uji T-tes antara kelompok tanduk gayor dengan tanduk ngabendo

\begin{tabular}{lcccccccc}
\hline $\begin{array}{c}\text { Profil } \\
\text { Tanduk }\end{array}$ & $\begin{array}{c}\Sigma \mathrm{n} \\
(\mathrm{ekor})\end{array}$ & $\begin{array}{c}\text { Volume } \\
(\mathrm{ml})\end{array}$ & $\mathrm{pH}$ & $\begin{array}{c}\text { Gerakan } \\
\text { masa }\end{array}$ & $\begin{array}{c}\text { Gerakan } \\
\text { individu (\%) }\end{array}$ & $\begin{array}{c}\text { Viabilitas } \\
(\%)\end{array}$ & $\begin{array}{c}\text { Abnormalitas } \\
(\%)\end{array}$ & $\begin{array}{c}\text { Konsentrasi } \\
(\text { Juta sel/ej) }\end{array}$ \\
\hline Gayor & 5 & $0,68 \pm 0,25$ & $6,96 \pm 0,10$ & $2,60 \pm 0,37$ & $63,00 \pm 12,88$ & $77,80 \pm 8,76$ & $5,33 \pm 0,56$ & $2.213 \pm 900$ \\
Ngabendo & 5 & $0,81 \pm 0,19$ & $6,79 \pm 0,15$ & $2,70 \pm 0,24$ & $64,00 \pm 7,35$ & $74,90 \pm 5,06$ & $6,03 \pm 0,71$ & $2.025 \pm 363$ \\
\hline Nilai P & 0,340 & 0,154 & 0,621 & 0,898 & 0,594 & 0,052 & 0,678 \\
\hline
\end{tabular}

Bobot badan domba garut tangkas terus meningkat sejalan dengan bertambahnya umur, begitu juga dengan lingkar dada, panjang badan, dan tinggi pundak (Tabel 1). Malewa (2009) menyebutkan bahwa semakin besar ukuran panjang badan dan lingkar dada, bobot badan domba semakin besar. Heriyadi et al. (2012) yang mengatakan bahwa sifat-sifat kuantitatif domba garut jantan di Jawa Barat pada kisaran umur 18-48 bulan antara lain rata-rata bobot badan domba garut jantan tipe tangkas sebesar $57,74 \pm 11,96 \mathrm{~kg}$, lingkar dada sebesar $88,73 \pm 7,58 \mathrm{~cm}$, dan panjang badan $63,41 \pm 5,72 \mathrm{~cm}$.

\section{Dewasa Kelamin dan Dewasa Tubuh}

Hasil penelitian menunjukkan bahwa kelompok umur 6-12 bulan sudah mengalami dewasa kelamin (Tabel 2). Garner dan Hafez (2000) menyatakan bahwa pada umur lebih dari 24 minggu domba mencapai dewasa kelamin dengan ukuran panjang, diameter, dan bobot testis adalah $10 \mathrm{~cm}, 6 \mathrm{~cm}$, dan 275 gram. Samsudewa dan Purbowati (2006) menyebutkan bahwa bobot testis, panjang testis, dan lebar testis domba jantan lokal pada umur tujuh bulan adalah 222,67 gram, 4,5 cm, dan $3,33 \mathrm{~cm}$. Soeparna (1984) menyebutkan bahwa kambing kacang jantan pertama kali mengeluarkan spermatozoa dalam ejakulatnya pada umur 20,23 $\pm 0,82$ minggu ( \pm 5 bulan) dengan bobot badan $7,74 \pm 0,57$ $\mathrm{kg}$, lingkar skrotum $11,91 \pm 1,34 \mathrm{~cm}$, dan panjang skrotum 5,62 $\pm 0,45 \mathrm{~cm}$.

Perkembangan bobot badan domba me-ningkat sejalan dengan pertambahan umur. Hal tersebut da- pat dilihat dari grafik yang terus meningkat sampai usia 36-48 bulan. Penambahan bobot badan dapat disebabkan oleh pertumbuhan fisik hewan atau penambahan deposit lemak dalam tubuh. Owens et al. (1993) menyebutkan bahwa dengan bertambahnya umur ternak dan asupan energi akan dihasilkan deposit lemak di antara otot (lemak intermuskuler), lapisan bawah kulit (lemak subkutan), dan di antara ikatan serabut otot, yaitu lemak intramuskuler (marbling).

\section{Karakteristik Fisik dan Kualitas Semen}

Yunardi (1999) menyatakan bahwa peningkatan umur berpengaruh sangat nyata pada pertumbuhan ukuran panjang, lingkar, dan volume skrotum. Parameter makroskopis yang diperiksa adalah volume, kekentalan, warna, dan $\mathrm{pH}$ (Tabel 3). Volume semen yang di-dapatkan pada penelitian ini masuk ke dalam kisaran normal. Garner dan Hafez (2000) menyebutkan bahwa volume semen domba berkisar antara 0,2-1,2 mL. Volume domba kelompok umur 36-48 bulan memiliki nilai terkecil. Aktivitas spermatogenesis pada umur yang semakin tua akan semakin menurun sehingga menghasilkan volume yang rendah (Heriyanta et al., 2013). Semen yang didapat berwarna krem dengan konsistensi kental. Hal ini sejalan dengan penelitian yang dilakukan oleh Feradis (2007), yaitu warna semen dipengaruhi oleh konsentrasi spermatozoa, yaitu semakin tinggi konsentrasi spermatozoa maka warna semen akan semakin keruh. Semen yang didapat memiliki pH dalam kisaran normal. Garner dan Hafez (2000) menyebutkan kisaran pH normal 
semen, yaitu antara 6,4-7,8. Sujoko et al. (2009) menyatakan bahwa semakin tinggi atau semakin rendah $\mathrm{pH}$ semen dari keadaan normal akan menyebabkan spermatozoa lebih cepat mengalami kematian.

Nilai persentase abnornalitas pada penelitian ini yang masih dalam kisaran normal (Tabel 4), nilai abnormalitas yang dapat ditolerir dan tidak mengakibatkan penurunan fertilitas untuk domba, yaitu kurang dari 15\% (Garner \& Hafez, 2000). Kisaran gerakan individu tersebut sesuai dengan kisaran semen segar domba mempunyai rata-rata gerakan individu sekitar 60-80\% (Garner \& Hafez, 2000; Bearden \& Fuquay, 2004). Gerakan individu spermatozoa dipengaruhi juga oleh umur, pada kelompok umur produktif gerakannya lebih besar dibandingkan dengan kelompok umur tua (Bearden \& Fuquay, 2004). Soeparna (1984) menyebutkan bahwa kambing kacang pada saat mencapai dewasa kelamin memiliki gerakan individu spermatozoa sebesar $62,25 \pm 12,56 \%$ dan nilai gerakan individu tersebut meningkat sampai $84,92 \pm 0,60 \%$ pada saat kambing kacang dewasa tubuh. Heriyanta et al. (2013) menyebutkan konsentrasi spermatozoa dipengaruhi oleh umur pejantan dan kecenderungan untuk meningkat seiring dengan peningkatan umur sampai 22 bulan.

\section{Bentuk Tanduk, Sifat Kuantitatif dan Kualitas} Semen

Kelompok bakalan memiliki nilai yang berbeda nyata dari kelompok tanduk lainnya dari nilai bobot badan, lingkar dada, panjang badan, tinggi pundak, lingkar skrotum, dan panjang skrotum (Tabel 5). Kelompok tanduk gayor, leang, dan ngabendo tidak memiliki nilai yang berbeda nyata pada bobot badan, lingkar dada, panjang badan, tinggi pundak, lingkar skrotum, dan panjang skrotum. Hal ini menunjukkan bahwa bentuk tanduk tidak berpengaruh signifikan pada sifat kuantitatif domba garut jantan tipe tangkas. Demikian pula dengan kualitas semen yang dihasilkan (Table 6). Nilai $P$ lebih besar dari 0,05 dari uji t-tes (Tabel 6) menunjukkan bahwa tidak ada perbedaan nyata antara hasil evaluasi semen domba garut bertanduk gayor dengan domba garut bertanduk ngabendo.

Evaluasi semen menunjukkan peningkatan kualitasnya pada kelompok umur 6-12 bulan sampai 18-24 bulan. Dewasa kelamin domba garut dimulai dari umur 6 bulan. Dewasa tubuh diperkirakan setelah mencapai umur 24 bulan. Setelah umur 24 bulan, evaluasi semen tidak menunjukkan perbedaan yang signifikan. Bentuk tanduk domba garut tipe tangkas tidak mempengaruhi sifat kuantitatif dan kualitas semen. Perlu dilakukan penelitian lebih lanjut dengan menggunakan sampel yang lebih banyak. Pertumbuhan fisik hewan coba diikuti dari lepas sapih sampai dewasa.

\section{UCAPAN TERIMA KASIH}

Ucapan terima kasih disampaikan kepada Program Diploma IPB yang telah mendukung penulis untuk melanjutkan studi pascasarjana Mayor Biologi Reproduksi, Fakultas Kedokteran Hewan, Institut Pertanian Bogor. Ucapan terima kasih juga disampaikan kepada Bapak Untung sebagai peternak domba garut yang telah memberikan izin untuk penggunaan domba garut jantan tipe tangkas dalam penelitian ini. Terima kasih juga disampaikan kepada saudara Musthamin Balumbi untuk kerja kerasnya selama pengambilan data di lapangan.

"Penulis menyatakan tidak ada konflik kepentingan dengan pihak-pihak terkait dalam penelitian ini".

\section{DAFTAR PUSTAKA}

Bagley CV. 1997. Examination of Rams: how to do it and how to intrepret it. http://extension.usu.edu/files/publications/fachsheet/AH_She ep_13.pdf. Download: April 1, 2017.

Bearden HJ, Fuquay JW. 2004. Applied Animal Reproduction. 4th ed. New Jersey : Prentice Hall. Upper Saddle, New Jersey.

[BSNI]. 2009. SNI Domba Garut no. 7532. http://sisni.bsn.go.id. Download : April 1, 2017.

Feradis. 2007. Karakteristik Sifat Fisik Semen Domba St. Croix. Jurnal Peternakan. 4 (1): 1-5.

Garner D L, Hafez ESE. 2000. Spermatozoa and Seminal Plasma. In : Hafez E. S. E. \& B. Hafez. Reproduction in Farm Animal. 7th ed. Lippincott Williams \& Wilkins, USA.

Gunawan A, Noor RR. 2005. Pendugaan nilai heritabilitas bobot lahir dan bobot sapih domba Garut tipe laga. Media Peternakan. 29:7-15.

Heriyadi D. 2005. Identifikasi Sifat-sifat Kualitatif Domba Garut Jantan Tipe Tangkas (Qualitative Traits Identification of Bantam Type Garut Ram). Jurnal Ilmu Ternak. 5 (2): 47-52. 
Heriyadi D, Sarwesti A, Nurachma S. 2012. Sifatsifat kuantitatif sumber daya genetik domba garut jantan tipe tangkas di Jawa Barat. Bionatura-Jurnal IImu-IImu Hayati dan Fisik. 14 (2) : 101-106.

Heriyanta E, Ihsan MN, Isnaini N. 2013. Pengaruh Umur Kambing Peranakan Etawah (PE) Terhadap Kualitas Semen Segar. Jurnal Ternak Tropika. 14 (2) : 1-5.

Hopkins FM, Spitzer JC. 1997. The New Society For Theriogenology Breeding Soundness Evaluation System. Vet Clin North Am Food Anim Pract. Vol 13(2):283-93.

Istiqomah L, Sumantri C, Wiradarya TR. 2006. Performa dan evaluasi genetik bobot lahir dan bobot sapih domba Garut di peternakan Domba Sehat Bogor. J. Pengemb. Peternakan Tropis. 31(4): 232-242.

Lindsay DR, Entwistle KW, Winatea A. 1982. Reproduksi Ternak di Indonesia. Fakultas Peternakan Universitas Brawijaya. Malang.

Malewa A. 2009. Penaksiran Bobot Badan Berdasarkan Lingkar Dada dan Panjang Badan Domba Donggala. J. Agroland 16. (1): 91-97

Owens FN, Dubeski P, Hanson CF. 1993. Factor that alter the growth and development of ruminant. J. Anim. Sci. 71: 3138 - 3150.

Pezzanite L, Bridges A, Nearly M, Hutchens T. 2004. Breeding soundness examinations of rams and bucks.http://www.extension.purdue.edu/extmed ia/ AS/AS-599-W.pdf. Download : Mei 6, 2017.

Samsudewa D, Probowati E. 2006. Ukuran organ reproduksi domba lokal jantan pada umur yang berbeda.http://peternakan.litbang.pertanian.go.i d/fullteks/semnas/pro06-62.pdf . Download : Mei 6, 2017.

Soeparna. 1984. Studi biologi reproduksi kambing kacang jantan muda. Disertasi S3. Fakultas Pasca Sarjana, Institut Pertanian Bogor. Bogor.

Sujoko, Heri, Setiadi MA, Boediono A. 2009. Seleksi Spermatozoa Domba Garut dengan Metode Sentrifugasi Gradien Densitas Percoll. Jurnal Veteriner. 10 (3): 125-132.

Trislawati L. 2006. Seleksi domba garut pejantan di peternakan ternak domba sehat Dompet Dhuafa Republika (TDS - DD Republika) berdasarkan ukuran-ukuran tubuh. Skripsi S1. Institut Pertanian Bogor. Bogor

Triwulaningsih EJ. 1986. Beberapa parameter genetik sifat kuantitatif kambing Peranakan Etawah. Tesis S2. Sekolah Pascasarjana, Institut Pertanian Bogor, Bogor.

Yunardi Y. 1999. Kajian kondisi fisik skrotum domba garut tangkas di desa Sukawargi kecamatan Cisurupan Kabupaten Garut (scrotal morphometry of the garut cibuluh sheep). Skripsi S1. Fakultas Peternakan, Institut Pertanian Bogor. Bogor. 